\title{
The Use of Google Classroom to Support the Learning Process:
} \section{Assessing Graduate Student Skills and Perceptions}

\author{
Zuhrieh Shana, Al Ain University, UAE \\ Tareq Mohamad Alyatim, Al Ain University, UAE \\ (iD https://orcid.org/0000-0003-0998-6112 \\ Mohammad Alkhazaleh, Al Ain University, UAE \\ Nahla Alshalabi, Al Ain University, UAE
}

\begin{abstract}
The purpose of this study is to assess the students' skills in creating virtual classrooms using the Google Classroom (GC) application through a 30 item questionnaire. In addition, the study used a Likert scale and an interview to explore students' perceptions towards GC. The sample consisted of 26 Master's students in the College of Education at Al Ain University in UAE. Data was generated from analyzing the questionnaire, and the Likert scale and the interview were used to answer the research questions. The results revealed that the degree of Master's students' skills in creating virtual classrooms was weak, and there are no statistically significant differences between students' skills based on gender and specialization. The results also showed that the perception of the GC was positive, and the majority of participants assured that GC is easy to create and use. They also expressed interest to learn more about GC through training. The findings from this study could be utilized by College of Education faculty members, students, administrators, and policymakers.
\end{abstract}

\section{KEYWORDS}

Al Ain University of Science and Technology, Education, eLearning, Google Classroom, Skills, Students, United Arab Emirates, Virtual Classrooms

\section{INTRODUCTION}

In recent years, the world has witnessed rapid developments in many fields, especially in information and communication technology (ICT). Technological progress has been introduced into all fields, including education which was affected hugely by ICT due to being a gateway to enlighten human's mind in order to develop and construct. Indeed, the role of ICT in education is increasingly becoming more important in the $21^{\text {st }}$ century (2013). Therefore, it was necessary for education to take advantage of employing ICT in the teaching and learning process as it contributes to increasing the interaction and reception of information (ibid) between students and teachers. Thus, the Internet started to play a key role to improve the effectiveness of teaching and learning in all levels (Arrieta, 2016) specially with the emergence of e-learning and its tools that serve the educational process in a way that helps learners to acquire experiences in different ways. As a result, new concepts emerged including: Virtual classrooms, e-courses, web-based learning, and learning management systems.

\section{DOI: 10.4018/IJWLTT.20210901.oa10}

This article, published as an Open Access article on July 9th, 2021 in the gold Open Access journal, the International Journal of Web-Based Learning and Teaching Technologies (converted to gold Open Access January 1st, 2021), is distributed under the terms of the Creative Commons Attribution License (http://creativecommons.org/licenses/by/4.0/) which permits unrestricted use, distribution, and production in any medium, provided the author of the original work and original publication source are properly credited. 
The rapid development of ICT has made the Internet a platform for the creation of information and knowledge. The Internet has made it possible to produce electronic educational media and establish new platforms of learning based on participation and cooperation and the provision of scientific content in various forms. The eighth scientific conference of the Egyptian Society for Educational Technology (2001) held in Cairo recommended paying attention to Internet-based e-learning resources and guiding scientific research towards the development of educational media on the Internet. Moreover, the Conference of Educational and Instructional Technology (2010) held in Gaza recommended employing modern Internet technology in the teaching and learning process. Taking these recommendations into consideration would provide the learner with access to the information and content required to complete the tasks of learning.

The interest in using digital technologies in e-learning has increased over time due to their ability in helping the learners in the learning process by accomplishing their works regardless of place and time (Al-Raheely, 2013), and by interacting with each other and with their teachers positively. Such technologies have also changed the role of the teacher to guide, plan, direct, facilitate and organize the teaching and learning process (ibid). One of these digital technologies is the Google Apps for Education (GAFE) platform of cloud based computing apps (Beaumont, 2018), which is a group of online applications that allow sharing and enhancing social presence in e-learning, and offering solutions for using technology in schools.

An example of these applications is Google Classroom, which is one of the innovative apps that brings the teacher and learners together in a virtual classroom with the aim "...to connect the class easily, track student progress and achieve more together" (Google for Education, 2018). Google Classroom app is designed to provide a single dashboard to unify instructors' use of other Google apps (Catapano, 2019). The app was tested by 100 thousand teachers from more than 45 countries, who confirmed the application effectiveness in accomplishing the tasks and achieving the teaching and learning process in its various components (Logofatu, Visan \& Ungurenanu, 2015).

Given that the faculties of education are responsible for graduating teachers and equipping them with the necessary skills to utilize technology (Tan, Choo, Kang \& Liem, 2017), they had to take advantage of the tremendous developments in the field of instructional technology. Providing the learners with the necessary tools for integration and living in a society that is advanced in terms of science and technology is the main role of the educational system. Thus, faculties of education have worked on developing the students' skills and knowledge in order to practice teaching in the future efficiently and effectively. As the virtual classroom is one of the components of the ICT revolution, education students must possess the essential scientific and practical knowledge on how to create, design and deal with the virtual classroom and employ it optimally so that they become well aware of such great technological application and its uses in education.

\section{PROBLEM STATEMENT}

Google has already made an impact on education with its Google Apps for Education. To name some are Google Docs, Google Spreadsheets, GC, and others that can be easily utilized by teachers and students. GC is a tool available for developing teaching and learning process all over the world as it can enhance students self-directed learning and cognitive skills (Maroof \& Emran, 2018). GC can have an effective role in developing the learners' learning abilities by improving their communication, interaction, writing and searching skills.

A number of research studies have been conducted on GC and many of them have been successfully implemented (Rion \& Hasan, 2015). These studies have addressed the effectiveness of virtual classrooms in raising the level of educational achievement, supporting students' learning and increasing the integration of learners with the scientific content and knowledge (Amour \& Alimat, 2016; Azhar \& Iqbal, 2018; Beaumont, 2018; Farmawi, 2010; Hegart \& Yoo, 2018; Maroof \& Emran, 2018). They also recommended making full use of the resources available for free on the 
Internet, especially Google virtual classrooms, in education field in order to enable students acquire the necessary knowledge and skills to deal with them. However, there is lack of studies that address students' skills in creating virtual classrooms using Google Classroom App among university students in general, and in the Gulf countries in particular.

Since the role of the College of Education at Al Ain University for Science and Technology (AAU) is providing the society with teachers equipped with the proper technological skills, it had to take advantage of the facilities offered by ICT and work on teaching and training the students on the use of the most important ICT applications used in education such as GC. Yet, after reviewing the curriculum related to instructional technology designed for the Master students at the College of Education, it was found that there is a clear shortage to address Web 2.0 applications in general and virtual classrooms in particular. It was also noticed that teaching some aspects related to Web 2.0 applications was theoretically only, without taking into account the practical aspect of the application, which provoked the researchers to conduct the current study.

\section{RESEARCH OBJECTIVES}

1. Explore the degree of master students' skills in creating virtual classrooms using GC application

2. Examine the differences between male and female students in terms of their skills in creating virtual classrooms a using GC application.

3. Examine the differences between Islamic education and Arabic language students in terms of their skills in creating virtual classrooms a using GC application.

4. Explore student perception towards GC in supporting teaching/learning process.

\section{RESEARCH QUESTIONS}

RQ1: What is the degree of master students' skills in creating virtual classrooms using GC application? RQ2: Do male and female students differ in terms of their skills in creating virtual classrooms using GC application?

RQ3: Do Islamic education and Arabic language students differ in terms of their skills in creating virtual classrooms using GC application?

RQ4: What is the participants perception of the effectiveness of GC in supporting teaching/learning process?

\section{SIGNIFICANCE OF RESEARCH}

With the scarcity of researches conducted on the importance of GC application in the teaching-learning process, the current research seeks to be one of the few contributing to the literature review in the area of instructional technology and e-learning resources. Adopting GC in the teaching-learning process may create an online community through the virtual learning environment. This would give more space for students and teachers -who should be skilled in creating and using virtual classrooms- to communicate bridging the gap created by formal and institutional rules. Moreover, the possibility for collaborative work between students and teachers offered by GC may support the approach of blended learning and its benefits including equipping both teachers and students with the digital skills necessary for survival in the $21^{\text {st }}$ century. 


\section{LITERATURE REVIEW}

\section{The Concept of Virtual Classrooms}

There are many synonyms for the term virtual classrooms such as electronic classrooms, smart classrooms, online learning, distance learning classrooms, live classrooms, and digital classrooms. Indeed e-learning plays a major role in promoting virtual learning through modern electronic media, since both e-learning and virtual learning are two terms with one goal that is the possibility for anyone to get access to education through Internet resources without having to go to any educational institution. Rion and Hasan (2015, p. 7) stated that "many developed countries are using virtual classroom to provide online education to the students".

Sayed (2017) defined virtual classrooms as "An interactive teaching and learning environment that allows live online interaction between the teacher and students, and works simultaneously and asynchronously as traditional classrooms, where the teacher and students work together at the same time regardless of the places they are at" (p. 373). In the same context Khleif (2011) defined virtual classrooms as "one of the main means of providing direct lessons and lectures on the Internet, in addition to distance training where the basic elements needed by both teacher and student are based on the interactive learning method" (p. 12).

Rizq (2009) indicated that virtual classrooms are similar to traditional ones in terms of teacher and students' presence, "yet they are available online, where teachers and students do not adhere to time or place, and can create virtual environments where students access through different networks to participate in collaborative learning". Also, Al-Salem (2004) defined virtual classrooms as "tools and software on the Internet that enable the teacher to share lessons, homework and tasks, and communicate with students through multiple techniques" (p. 21). In the meantime, these tools and software enable the students to read the lessons and do the homework and tasks, as well as "participate in discussion forums and follow up on their academic achievement and the degrees obtained" (ibid).

Regardless of the definition, virtual classroom is surely an exceptional part of the learning systems in online education (Rion \& Hasan, 2015). Indeed, virtual classrooms are getting commended for providing students with quality education. Abdulrazeq (2010) mentioned a number of elements and components that characterize the structure of the virtual classrooms on the Internet including: Home page, log in tool, learning content pages, communication tools (synchronous and non-synchronous) including e-mail, chat rooms and forums, self-test tool, timetable of the content, tools to communicate to search engines, activities and assignments tools, educational resources, setting control panel, and organizational map.

\section{Advantages of Virtual Classrooms}

In order to make full use of the advantages of virtual classrooms, there must be a connection to the Internet or a local information network (Intranet), in addition to the availability of an electronic management system and a follow-up system by both the teacher and the school or university to ensure the virtual classrooms objectives are being achieved. Also, students should have good computer skills, while teachers should have good deal of knowledge about virtual classrooms and how to interact with students through them.

Al-Salem (2004) states several important advantages of virtual classrooms, which are: (i) achieve application sharing, (ii) provide immediate feedback to the learner, (iii) direct interaction between teacher and learner, (iv) interactive content with all its elements, (v) direct verbal chat, (vi) interacting with a large number of participants from different places, (vii) supporting scientific content with multimedia, (viii) navigating different educational sites online in class, and (ix) provide direct assessment.

Abu Alia (2013) on the other hand mentions other advantages of virtual classrooms including: 


\section{The Teacher's Role in The Virtual Classroom}

Students prefer the engagement in GC where teachers have passive roles, rather than being engaged in a class where teachers have the main role (Maroof \& Emran, 2018). A proper virtual classroom must be flexible and allows the teacher to explain the educational content in more than one language, use multimedia, include an efficient control panel that allows ease of use, and include the main functions of electronic classrooms (Mwanza, 2005). This requires new roles from the teacher in the virtual classrooms as mentioned by Mwanza as follows:

1. The teacher transforms from simply a teacher providing information to an instructor providing students with educational resources guiding them on exchanging knowledge.

2. The teacher encourages students to work in groups to increase their learning experiences and to share these experiences.

3. The teacher seeks to achieve quality teaching through competition with his colleagues.

4. The teacher encourages students to deal with educational subjects with multiple perspectives.

5. The teacher inspires students to become self-independent, and manage time and learning process.

Furthermore, Al-Talwaty (2014) enlists the following tasks for the teacher in the virtual classroom:

1. Define the objectives and outcomes of the lessons and the courses that he seeks to achieve.

2. Select or prepare assessment methods to measure the extent of achieving these objectives.

3. Follow up on students' attendance and academic progress and attainment.

4. Organize the learning environment by making it comfortable, cooperative, and interactive.

5. Instruct students to do assignments, activities and projects and conduct discussions.

6. Ask questions that provoke understanding and critical thinking and accept different answers.

7. Provide academic assistance and guidance to students and solve their academic problems.

\section{Google Classroom and Its Characteristics}

Google Apps for Education (GAFE) is an influential cloud-computing solution that works to connect and engage with every student no matter where they are and what tools are used (Google, 2013). The GAFE suite includes Gmail, Google Drive, Google Groups, Google Calendar, Google Docs, Google Sites, and Google+ (Google, 2013). The integration of GAFE tools have been used to overcome barriers that students have in communicating with their teachers within classroom settings (Sviridova, Sviridova, \& Tymoshenko, 2011) and increase productivity and learning gains in the classroom.

Google Classroom is a free application that is part of GAFE. Its purpose is to facilitate communication and interaction between teachers and students and streamline educational workflow (Catapano, 2019). It has been launched in May 2014 (Beaumont, 2018) and is currently available in 42 languages. GC provides a unique experience for students and teachers in managing the daily tasks and activities. GC "uses Google Cloud to save and share files between students and teachers with the possibility of keeping track of students' progress in performing the daily tasks and it is free" (Amour \& Alimat, 2016, p. 156).

In order to use GC, an e-mail account should be created for each student. Teachers can add students to classrooms, where they can post students' e-mail addresses. GC can also upload the student's Gmail contacts, or export members of Google Groups. Teachers can create classes, post assignments, organize folders, and view work in real-time (Beaumont, 2018; Catapano, 2019). The app also allows teachers to "constantly control their observations, surveys, and analyses of student's demography” (Maroof \& Emran, 2018, p. 3).

Another important characteristic of the application is that the way students are added to the classroom by coding is obtained from the application and sent by the teacher, which enables the students to join the class, and there is ability to reset or disable the encoding by clicking on the 
encoding itself. Further, the teacher can create the desired number of classrooms, and students can join the classes they want. Once the invitation has been sent, the teacher can follow up the status of each invited person. The teacher can also give permission to students, and read any comments and messages written by students.

Google has stated the following characteristics of its GC application (Lujvato, Vesan \& Angorino 2015):

1. Prepare and collect assignments: GCs combine Google Docs, Google Drive, and Gmail to help teachers prepare and collect paperless assignments, know who did or did not submit the assignment, and provide direct feedback to each student.

2. Improve class interaction: Teachers can make announcements, ask questions and comment on students' performance instantly, and improve interaction inside or outside the classroom.

3. Maintain the organization: The classrooms may have folders for each assignment and each student, and students can follow up on the results and feedback provided by teachers.

Many students prefer using GC in their learning process due to its usefulness, ease of use, and practicality in accomplishing the intended tasks (Maroof \& Emran, 2018). They can begin working with just one click by viewing the assignment, and then when opening a Google Doc teacher will have a real-time view into their students' progress which allows them to offer feedback and comments along the way (Catapano, 2019).

\section{Previous Studies}

In reviewing the literature, the following studies were found in relation to Google virtual classrooms:

Peterson (2013) explored teachers' perceptions of using Google Apps to produce digital content and in communication and collaboration. The study sampled 86 teachers at the University of Hawaii, America, who were asked to use some of Google Apps (Google Docs, Google Sites, Google Presentations, GCs) in the teaching process. The results revealed that the teachers were familiar with the Apps that were effective in producing the educational content, communicating and cooperating with teachers and students. Similarly, Azhar and Iqbal (2018) assessed teachers' perceptions of GCs. The study sampled 12 teachers at Barrett Hodgson University using semi-structured interviews. The results indicated that teachers perceived Google virtual classroom as a convenient tool in document and classroom management, has a significant positive impact on teaching methods, and has an easy-to-use interface. Also, Beaumont (2018) explored the perceptions of using GCs from students and educators' perspective at the student learning department of Keele University, UK. The results showed that the feedback was very positive, where students perceived GCs as easy to use, engage in discussions, answer and pose questions. Meanwhile, educators perceived GCs as easy to create and enroll individuals or groups of students in, and they indicated being able as educators to use the assessment function.

Dicisio (2016) explored the effect of using GCs in teaching social studies for students with learning disabilities. The researcher sampled 7 students from grade seven and 5 teachers, and used an achievement test, vocabulary test and a questionnaire to collect data. The results showed that using GCs increased the students' academic achievement and vocabulary. Yet, the results showed a limited understanding of the content by students. Alamour and Elimat's (2016) study in the Negev district in Palestine explored the effectiveness of GCs in acquiring biological concepts. The sample consisted of 133 students from grade 10 in public schools. The sample was divided into experimental and control groups, and the researchers used an achievement post-test to measure the students' acquisition of concepts. The results revealed that the experimental group acquired biological concepts through GCs, indicating its effectiveness in the teaching process.

Hegart and Yoo (2018) also explored the effectiveness of using GCs for final year primary teacher education students to identify how the application can influence future pedagogies at the tertiary 
level. The study sampled 33 primary school pre-service teachers and used survey, focus groups and observation. The results showed that GCs increased students' participation and learning and made learning faster and effective, and revealed that GCs are as easy to use. The study provided a framework that may help educators in tertiary institutions in using the available technologies.

Rion and Hasan's (2015) study aimed to provide an effective teaching and learning system for learners living in remote areas in Bangladesh. The researchers implemented a model of interactive virtual classroom that provides real-time interactive classes with the collaboration of teachers and students in one portal. The study found that virtual classroom minimizes the physical barriers between teachers and students, and that the performance of teaching-learning outcome was satisfactorily good. Finally, Maroof and Emran (2018) examined the factors that affect the students' acceptance of GC at a University College in Oman. The researchers adopted TAM model and used an online questionnaire to collect data from 337 respondents. The results showed that both perceived ease of use and perceived usefulness influence the students' intention positively, which in turn influences their actual usage of GCs.

\section{METHODOLOGY}

\section{The Course Activities}

According to the fact that simply adding educational technology to a learning environment doesn't guarantee better learning outcome. Moreover, when it comes to teaching and learning, it's not what technology you use, but when, why and how you use it that counts. Therefore, in our course our main emphasis is based on technology integration starting from Dale Cone of experience up to different models of technology integration. SAMR is one of the current models that enlightens teacher adoption of technologies that support the integration of technology into student learning experiences.

According to Edgar Dale's Cone of Experience (1969), people learn, retain and remember 10\% of what they read, $20 \%$ of what they hear, $30 \%$ of what they see, $50 \%$ of what they see and hear, $70 \%$ of what they say and write, and $90 \%$ of what they do (see Figure 1). The arrangement in the cone is not based on the level of difficulty, but on the abstraction and number of senses involved.

Two commonly used models for technology integration are known as SAMR and TPACK. In our course SAMR model was adopted. According to Kihoza, Zlotnikova, Bada, \& Kalegele, SAMR model is a tool for "... assessing and evaluating technology practices and impacts in the classroom setting" and can be examined at both the student and teachers' levels (2016, p.108). The acronym SAMR consists of four levels of integration (substitution, augmentation, modification, and redefinition) that provides a guide for educators to expect their integration levels.

According to SAMR, to adopt technology, planning has always to start by asking questions such as

- Why do we need this technology?

- What do we want technology to help us achieve?

The answers to such questions will determine the basis of technology selection and the level of technology integration according to SAMR model (Figure 2).

On the other hand, El Mansour \& Mupinga (2007, p. 242) proposed that,

...as higher education institutions struggle to meet the growing demand for education from nontraditional students, many are turning to hybrid and online courses. These courses, free up classroom space, allow faculty to reach a wider audience using technology; and are therefore cost effective.

Clark and Avrith (2017) supported the same idea. He suggested Classroom since it blends Google tools in one place that anyone with a Google account can use. 
Figure 1. Cone of Learning Experience from Wikipedia (Jeffrey Anderson)

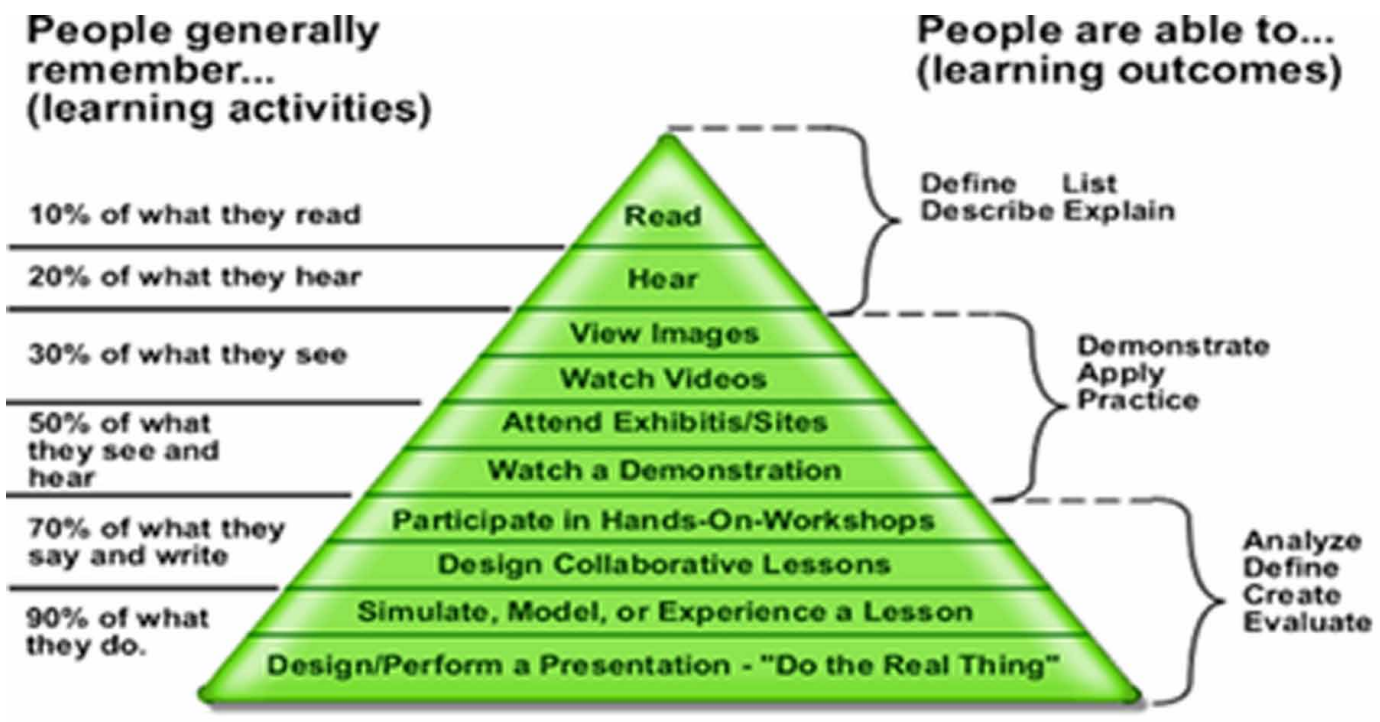

Figure 2. SAMR model (Puentedura, 2003)

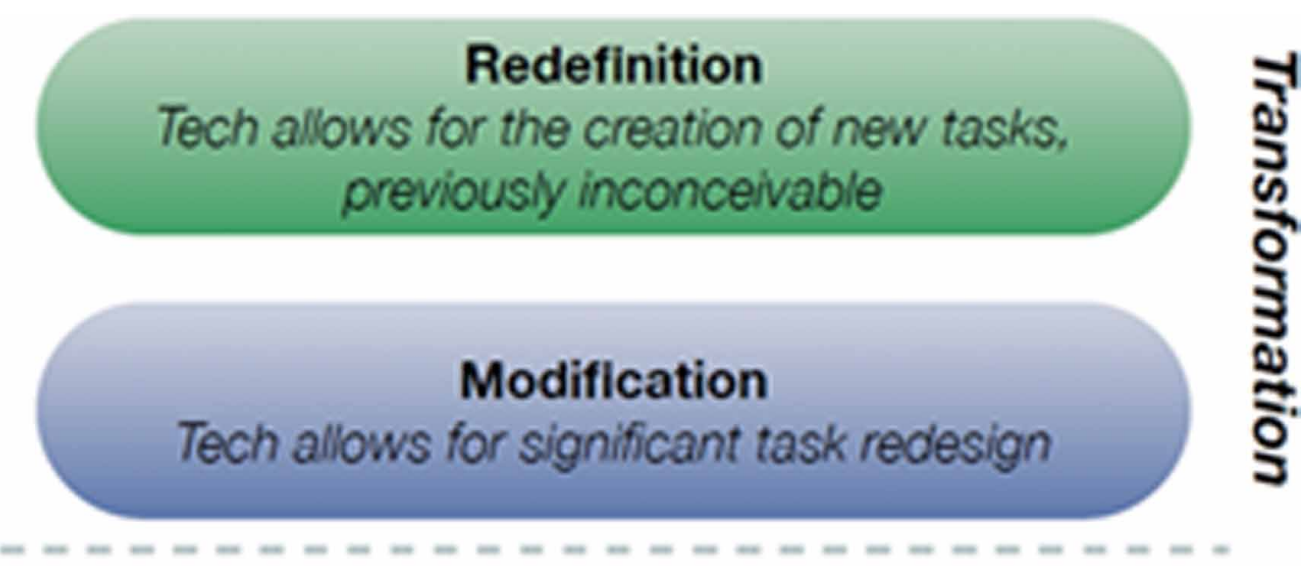

\section{Augmentation \\ Tech acts as a direct tool substitute, with functional improvement}

\section{Substitution}

Tech acts as a direct too/ substitute, with no functional change 
For the above-mentioned facts, at the end of the integration unit, students were asked to do the assignment regarding technology integration. This assignment is intended to be a challenging exercise that provide a practice to knowledge and skills needed to perform technology integration. It also helps enhance understanding of SAMR models' principles of technology integration by applying them to an authentic teaching activity.

\section{Course Project Description}

Create a PowerPoint presentation that could be used to teach a selected lesson from your major to students in your class. The presentations must align with SAMR model of technology integration and should include the advanced features of PowerPoint of sound, insertion of still pictures, video clips, etc. You are expected to submit four versions of the power point that represent each level of SAMR model (Figure 2).

\section{Requirements}

1. Alignment with Objective - The presentation is aligned with SAMR model and your selected topic or objective. The topic or objective is selected from your major and the grade level you intend to teach.

2. Instructional Design - The material presented follows instructional design principles, such a progressing logically, going from simple to complex progression, etc.

3. Design Principles - As the presentation is viewed, it is apparent that instructional design principles have been applied appropriately in the creation of the presentation. These principles include effective use of color, appropriate size of text and font, appropriate use of graphics, etc. Be sure to appropriately cite all resources used and include a closing slide listing those resources.

4. Interactivity - The presentation is interactive. It should require the student to be actively engaged using input devices that are appropriate to the concept being taught at the age level designated.

5. Navigation - The presentation is easy for the learner to navigate through. It should not require much technical knowledge for the student to be successful.

6. Multimedia - The presentation includes the appropriate use of three multimedia elements from the following list: video clips, still images, sound, animation.

7. Written Report - Your presentation should be accompanied by a written report that includes:

a. Objectives for the presentation

b. Plan for using the presentation in teaching

c. Explain how your presentation aligns with the SAMR model for technology integration;

8. Oral Presentation

\section{Research Design}

This study used a quantitative analytical descriptive approach to answer the research questions. The descriptive research is defined as "the approach that is based on studying the phenomenon as it is in reality, and is not limited to collecting data and facts, rather it also classifies and analyzes them and then comes out with the results"(Aldwaidri, 2000, p. 183). It aims to identify a given situation completely and carefully (Şahin, 2013) and to describe a phenomenon and its characteristics. This type of research is more concerned with 'what' rather than 'how' or 'why' something has happened (Nassaji, 2015). Observation and survey are some of the widely used methods to collect data (Gall, Gall \& Borg, 2007), which are often analyzed quantitatively using frequencies, percentages, averages, or other statistical tests (Nassaji, 2015). Thus, for this research, several data collection tools were used including survey/questionnaire, Likert scale questions and an interview. 


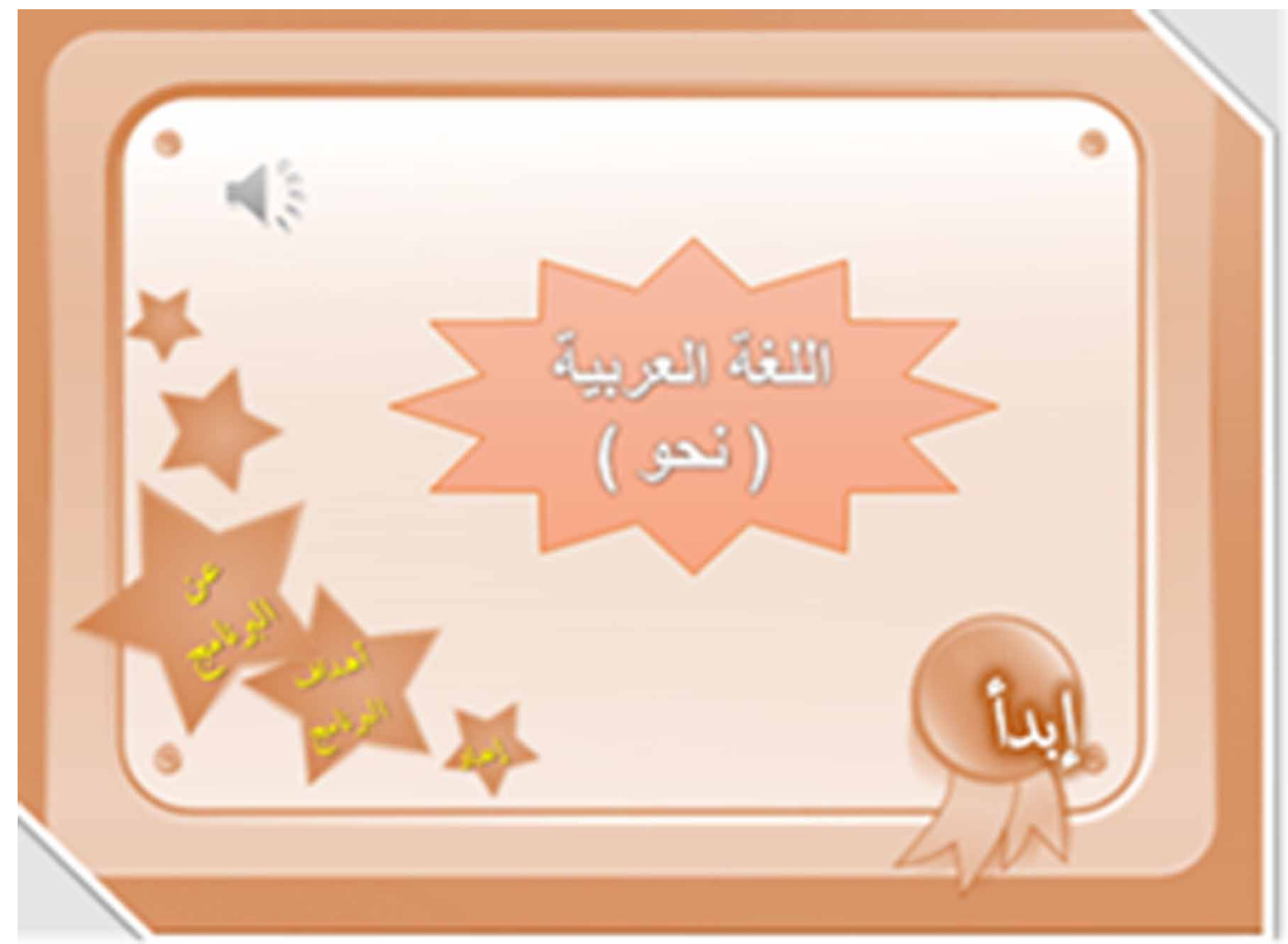

\section{Research Participants}

Although random sampling is the best for fair and justified sampling, one of the most common methods of sampling is a non-random method called purposive sampling, which selects participants for a specific reason. This study used purposive sampling where the researcher selected the sample based on who would be proper for the study. Purposive sampling can be defined as a method that uses a sampling unit within the sector of population with information of a phenomenon of interest (Guarte and Barrios, 2006).

The total number of students enrolled in educational technology course and willing to participate in the study is 28 . Two students were excluded, primarily because they were absent, for personal reasons, on the days of the meeting workshops. Thus, the actual study sample is $(n=26)$. Research participants consists of students that completed the questionnaire, responded to Likert scale statements and participated in the Interview/discussion.

Therefore, the research participants were drawn from AAU students who were enrolled in the Educational Technology course and willing to participate in this study. It was conducted on a sample of master students in the College of Education at AAU in Abu Dhabi during the first semester of 2018/2019 academic year. The sample consisted of 26 students, 20 of them are pursuing their master degree in Arabic language while the other 6 are in Islamic education.

\section{Research Instrument}

\section{Questionnaire}

Assessment data can be obtained from directly from a wide range of assessment tools such as paperand-pencil tests, interview, observations, questionnaire, portfolios, and oral presentation. Thus, educational assessment or educational evaluation is the systematic process of recording and using 


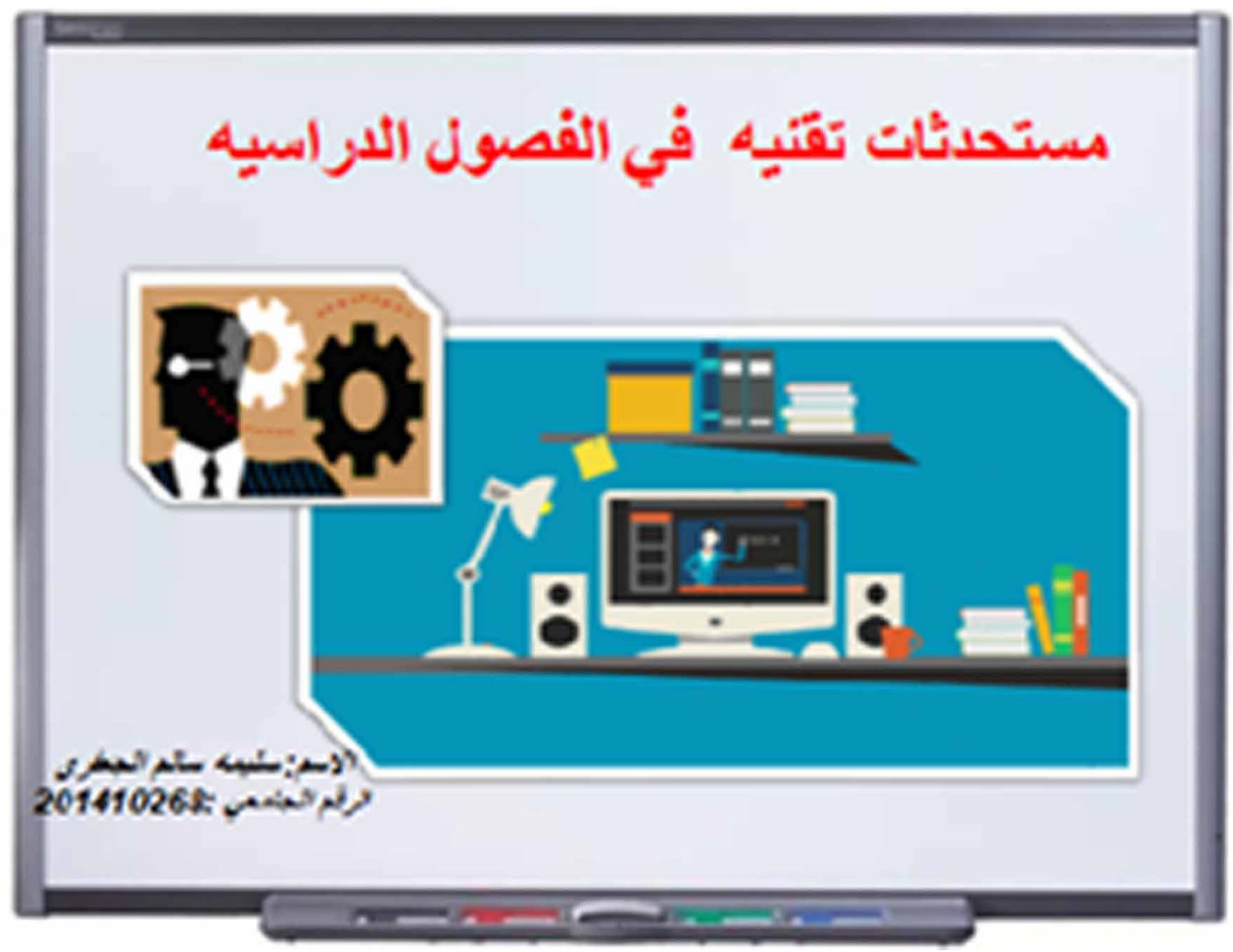

empirical data on the knowledge, skill and attitudes to refine programs and improve student learning. It focuses on to obtaining information about students is used for making decisions about students, curricula activities and educational programs (Parker \& Gerber, 2002).

The instrument used to collect assessment data was a questionnaire that consisted of items inspecting the students' skills of creating virtual classrooms using the GC application. The questionnaire is "a systematic survey tool as it begins with identifying the required data and ends with receiving the forms, and is also codified because its organization is in a typical way saves time, effort and expenses" (Abdulhamid, 2005, p. 351). The questionnaire items were created based on the relevant literature and practically practicing the skills. Then, the items were modified to match the current study and validated by a number of arbitrators in the field.

As a guideline for developing this questionnaire, Dillman's (2000) main principles were followed, specifically: 1 . Purpose of the instrument; 2 . Specifications; 3. Items pool; 4. Pretesting and final form.

1. Purpose of the instrument:

The researchers, who were also the instructors, developed a questionnaire to determine and assess the students' skills in creating virtual classrooms. The questionnaire is consisted of items inspecting students' skills of creating virtual classrooms using the GC application.

2. Specifications: 
Questionnaires are considered as one of the crucial sources of attaining data in any research. Nevertheless, the questionnaire has to be "valid, reliable and unambiguous" (Richards \& Schmidt, 2002, p. 438).

\section{Items pool}

Before sharing the questionnaire with the targeted participants, the researchers conducted a pilot study on a sample of 14 students of the population in order to measure the questionnaire reliability. The pilot study helped to identify and correct the mistakes in set questions. It can even determine the suitability and the appropriateness of the language used in the questionnaire.

\section{Pretesting and final form.}

The finalized questionnaire consisted of two parts: the first one inspected the participants' demographics including gender, age, and specialization. The second part consisted of 30 items on the necessary skills for creating a virtual classroom using GC application.

Consequently, the questionnaires were collected for analysis. The data collected were computed in IBM statistical Package for Social Sciences (SPSS) 19, allowing the researchers to do the relevant statistical analysis. Using the proper tests to analyze the data, the researchers came up with the results. The sample descriptive characteristics were assessed based on the demographic information including gender, age, year of study, and specialization.

In order to answer the first research question, the mean scores and standard deviations were calculated, as well as the total score in order to measure the degree/extent of skills for the master students. In addition, and in order to answer the second and third research questions, Man-Whitney $\mathrm{U}$ Test was used to find the differences between the male and female students as well as between the Arabic language and Islamic education students.

In order to determine the degree of students' skills of creating virtual classrooms using GC application, the responses of the participants were given gradual values according to the scale described previously (see Table 1) as follows:

a. Calculate the range by subtracting the largest value in the scale from the smallest value $(3-1=2)$.

b. Calculate the length of category by dividing the range on the number of categories $(2 \div 3=$ $0.66)$.

c. Add the category length (0.66) to the smallest value in the scale (1) to obtain the range for the first category, which is from 1 to 1.66 , and then add another $(0.66)$ to obtain the range for the second category, which is from 1.67 to 2.33 , and one more time to obtain the range for the third category, which is from 2.34 to 3 (number 3 is the highest value in the scale). The categories and equivalent degrees used to judge the mean scores are shown in Table 4.

\section{Validity of Questionnaire}

For the validity of the questionnaire items, the questionnaire was verified by content validity. The questionnaire items were tested to ensure consistency, clarity, wording comprehensibility, and ease of understanding through having the questionnaire pre-tested by a group of arbitrators at the College of Education who are specialized in teaching, assessment and evaluation techniques. The specialized arbitrators' remarks and comments were reflected in terms of words clarity, comprehensibility of the items and their relevance to the subject by re-writing and re-arranging some items.

Before sharing the questionnaire with the targeted participants, the researchers conducted a pilot study on a sample of 14 students of the population in order to measure the questionnaire reliability. In order to measure the questionnaire reliability, the researchers measured its internal consistency using Cronbach's Alpha value, which ranges between 0 indicating lack of internal consistency and 
1 indicating perfect internal consistency (Skaik, 2016). Consequently, the closer the value to 1, the higher the reliability coefficient of the items (ibid). The result of the reliability test showed high internal consistency for the items and an overall Cronbach's alpha of 0.87 for the questionnaire, which supports the appropriateness of the questionnaire and indicates its reliability.

The finalized questionnaire consisted of two parts: the first one inspected the participants' demographics including gender, age, and specialization. The second part consisted of 30 items on the necessary skills for creating a virtual classroom using GC application. The participants were asked to estimate their skills as either weak, moderate or high, which each was assigned a degree from 1 to 3 (see Table 1). Thus, the total score of a student's answers is limited between 30 to 90 degree.

Table 1. The answer and degree scale

\begin{tabular}{|c|c|c|c|}
\hline Answer & Weak & Moderate & High \\
\hline Degree & 1 & 2 & 3 \\
\hline
\end{tabular}

\section{DATA COLLECTION AND ANALYSIS}

After the completion of the questionnaire design, and making the necessary changes based on the pilot study, data were collected from the sample during the first semester of 2018/2019. The questionnaire was distributed traditionally in hard copies to the study sample, and were asked to answer all questionnaire items by giving the sufficient time. Then, the questionnaires were collected for analysis.

In order to answer the first research question, the mean scores and standard deviations were calculated, as well as the total score in order to measure the degree/extent of skills for the master students. In addition, and in order to answer the second and third research questions, Man-Whitney $\mathrm{U}$ Test was used to find the differences between the male and female students as well as between the Arabic language and Islamic education students.

In order to determine the degree of students' skills of creating virtual classrooms using GC application, the responses of the participants were given gradual values according to the scale described previously (see Table 1) as follows:

d. Calculate the range by subtracting the largest value in the scale from the smallest value $(3-1=$ 2).

e. Calculate the length of category by dividing the range on the number of categories $(2 \div 3=$ $0.66)$.

f. Add the category length (0.66) to the smallest value in the scale (1) to obtain the range for the first category, which is from 1 to 1.66 , and then add another (0.66) to obtain the range for the second category, which is from 1.67 to 2.33 , and one more time to obtain the range for the third category, which is from 2.34 to 3 (number 3 is the highest value in the scale). The categories and equivalent degrees used to judge the mean scores are shown in Table 2.

\section{Likert Scale Questions and Interview}

In order to assess their perceptions on the integration process, participants were asked to respond to a questionnaire consisting of five Likert-scale items. The options for answering each question were: (1) Agree, (2) Undecided, and (3) Disagree.

The Likert scale component comprised the following five items:

Technology Integration helped my students to: 
Table 2. Categories of mean scores for each degree

\begin{tabular}{|c|c|}
\hline Categories of mean scores & Degree \\
\hline From 1 to 1.66 & Weak \\
\hline From 1.67 to 2.33 & Moderate \\
\hline From 2.34 to 3 & High \\
\hline
\end{tabular}

- understand better and need less explanation.

- collaborate more and stay engaged.

- learn at their own pace.

- access information at any time.

- enjoy the learning experience.

At the last meeting of the technology integration unit, the questionnaires were distributed to all participant. A total of 26 completed questionnaires were received. The results of the Likert scale questions are summarized in the table 3.

Table 3. The percentage of the research participants who agreed on Likert scales' statements

\begin{tabular}{|c|c|c|}
\hline Participants (26) & Arabic Language (20) & Islamic Education (6) \\
\hline Agree & $85 \%$ & $100 \%$ \\
\hline Undecided & $10 \%$ & $0 \%$ \\
\hline Disagree & $5 \%$ & $0 \%$ \\
\hline
\end{tabular}

To elaborate on the previous students' responses to the Likert scale item, the researcher developed a semi structured interview based around the following open-ended questions:

Please comment on the value of the Google Class creation process as a blended/virtual teaching and learning environment.

1. Do you believe that $\mathrm{GC}$ is useful in facilitating teaching and learning in both inside and outside classroom?

2. What is your opinion on creating and using GC? Is it easy or difficult to use?

3. Do you need an extra help and training creating and using GC?

All participants were interviewed. The average length of time for the interviews was approximately 15 - 20 minutes per student. The questionnaire consisted of the above main question. The questions were in English but to reduce the language "barrier", English questions were translated into Arabic and students had the choice of answering the questions in English or Arabic. To summarize the findings of these interviews $80 \%$ of the supported the idea of the Google Class, considering it an effective way to teach and learn, to access required curriculum knowledge and skills and better to understand their major. this research question additionally two sub questions. 


\section{RESULTS}

This section presents the results of the data analysis in order to answer the research questions.

RQ1: What is the degree of master students' skills in creating virtual classrooms using GC application?

To answer this question, the averages, mean scores and standard deviations for the questionnaire item were calculated. Table 4 below shows that the general mean score for the total number of statements inspecting students' skills in creating virtual classrooms using GC application was (1.14). The mean scores for the questionnaire items ranged from 1 to 1.42 indicating that the students' skills are weak according to the scale shown in Table 2 above.

RQ2: Do male and female students differ in terms of their skills in creating virtual classrooms using Google Classroom application?

In order to answer the second research question on the statistical differences between male and female students' skills in creating virtual classrooms, Man-Whitney U test was conducted. Based on the results as seen in Table 5 below, the $\mathrm{Z}$ value is 0.11 (rounded) with a significance level of $\mathrm{p}=0.91$. The probability value (p) is not less than or equal to .05, so the result is not significant. Therefore, there is no statistically significant difference in the students' skills scores of males and females.

RQ3: Do Islamic education and Arabic language students differ in terms of their skills in creating virtual classrooms using Google Classroom application?

In order to answer the third research question on the statistical differences between Arabic language and Islamic education students' skills in creating virtual classrooms, Man-Whitney U test was conducted. Based on the results as seen in Table 6 below, the $Z$ value is 0.71 with a significance level of $\mathrm{p}=0.47$. The probability value ( $\mathrm{p}$ ) is not less than or equal to .05 , so the result is not significant. Therefore, there is no statistically significant difference in the skills scores of Arabic language and Islamic education students.

RQ4: What is the participants perception of the effectiveness of GC in supporting teaching/learning process?

To obtain answers to the fourth research question, the generated result of participants' responses to Likert scale statements and the interview should be collected, analyzed and interpreted.

1. Do you believe that GC is useful in facilitating teaching and learning in both inside and outside classroom?

The responses to Likert scale statements were very positive. $75 \%$ of Arabic language and 100\% of the Islamic Education's students rated GC as strongly supporting teaching and learning process in both inside and outside classroom (Figure 5).

1. What is your opinion on creating and using GC? Is it easy or difficult to use?

2. Do you need an extra help and training creating and using GC? 
Table 4. Means, standard deviation, and the degree of students' skills

\begin{tabular}{|c|c|c|c|c|}
\hline No & Skill & Mean & $\begin{array}{c}\text { St. } \\
\text { Dev. }\end{array}$ & Degree \\
\hline 1 & I have the skill to access GC site & 1.19 & 0.40 & Weak \\
\hline 2 & I can find the icon for creating a virtual classroom in GC app & 1.08 & 0.27 & Weak \\
\hline 3 & $\begin{array}{l}\text { I have the skill to enter the information required for creating virtual } \\
\text { classroom in the designated fields }\end{array}$ & 1.35 & 0.48 & Weak \\
\hline 4 & I have the skill to change the interface of the virtual classroom & 1.23 & 0.43 & Weak \\
\hline 5 & I can access the sharing forum & 1.42 & 0.57 & Weak \\
\hline 6 & I have the ability to add learners to the virtual classroom & 1.08 & 0.27 & Weak \\
\hline 7 & I have the skill to determine the teachers' authorities in the virtual classroom & 1.08 & 0.27 & Weak \\
\hline 8 & $\begin{array}{l}\text { I have the skill to display the code for adding learners in the virtual } \\
\text { classroom }\end{array}$ & 1.35 & 0.48 & Weak \\
\hline 9 & $\begin{array}{l}\text { I have the skill to add learners to the virtual classroom according to the code } \\
\text { of the virtual classroom }\end{array}$ & 1.04 & 0.19 & Weak \\
\hline 10 & $\begin{array}{l}\text { I have the skill to add learners to the virtual classroom using the e-mail of } \\
\text { each learner }\end{array}$ & 1.27 & 0.45 & Weak \\
\hline 11 & $\begin{array}{l}\text { I have the ability to determine the learners' authorities in the virtual } \\
\text { classroom }\end{array}$ & 1.00 & 0.00 & Weak \\
\hline 12 & I know how to classify learners' names in the virtual classroom & 1.12 & 0.32 & Weak \\
\hline 13 & I can send an email in the virtual classroom to each learner alone & 1.12 & 0.32 & Weak \\
\hline 14 & I have the skill to create a subject in the virtual classroom & 1.38 & 0.63 & Weak \\
\hline 15 & I have the ability to publish a subject in the forum & 1.00 & 0.00 & Weak \\
\hline 16 & $\begin{array}{l}\text { I have the skill to create classifications for each subject in the virtual } \\
\text { classroom }\end{array}$ & 1.08 & 0.27 & Weak \\
\hline 17 & $\begin{array}{l}\text { I have the ability to link the subject to the classification in which it should } \\
\text { appear }\end{array}$ & 1.08 & 0.27 & Weak \\
\hline 18 & I can enclose the learners' assignments in the virtual classroom & 1.00 & 0.00 & Weak \\
\hline 19 & I can save the learners' assignments in the virtual classroom in my computer & 1.00 & 0.00 & Weak \\
\hline 20 & $\begin{array}{l}\text { I have the skill to create essay questions for the learners in the virtual } \\
\text { classroom }\end{array}$ & 1.08 & 0.27 & Weak \\
\hline 21 & $\begin{array}{l}\text { I have the skill to create objective questions for the learners in the virtual } \\
\text { classroom }\end{array}$ & 1.04 & 0.19 & Weak \\
\hline 22 & $\begin{array}{l}\text { I know how to determine the grade of each question created in the virtual } \\
\text { classroom }\end{array}$ & 1.12 & 0.32 & Weak \\
\hline 23 & $\begin{array}{l}\text { I have the skill to determine the learners' authorities about the question (for } \\
\text { example, modify his/her answer) }\end{array}$ & 1.27 & 0.53 & Weak \\
\hline 24 & I have the skill to access the icon that shows the learners' answers & 1.12 & 0.32 & Weak \\
\hline 25 & $\begin{array}{l}\text { I know how to send grades to learners on their answers to questions in the } \\
\text { virtual classroom }\end{array}$ & 1.08 & 0.27 & Weak \\
\hline 26 & I know how to send feedback to learners & 1.12 & 0.32 & Weak \\
\hline 27 & $\begin{array}{l}\text { I have the skill to create an interactive assignment (homework) for learners } \\
\text { and send it to them }\end{array}$ & 1.04 & 0.19 & Weak \\
\hline 28 & I can follow up on the interactive assignm ent of learners & 1.12 & 0.32 & Weak \\
\hline 29 & $\begin{array}{l}\text { I have the ability to download the file for each learner in the virtual } \\
\text { classroom }\end{array}$ & 1.31 & 0.47 & Weak \\
\hline \multirow[t]{2}{*}{30} & I have the ability to print the file for each learner in the virtual classroom & 1.27 & 0.45 & Weak \\
\hline & Total score $=34.38 / 30$ & 1.14 & 2.04 & Weak \\
\hline
\end{tabular}

As for these questions, the result was unanimous in which $100 \%$ of the research participants had the belief that GC was easy to create and use. In spite of this fact, the participants also agreed that they still need more training in creating and the Google Class. 
Table 5. Differences between students according to gender

\begin{tabular}{|c|c|c|c|c|c|c|c|}
\hline $\begin{array}{c}\text { Skills in creating } \\
\text { virtual classrooms }\end{array}$ & Group & No & $\begin{array}{c}\text { Mean } \\
\text { Rank }\end{array}$ & $\begin{array}{c}\text { Sum of } \\
\text { Ranks }\end{array}$ & Man-Whitney & Z value & P value \\
\hline \multirow{3}{*}{} & Males & 10 & 13.30 & 133 & 78.00 & 0.108 & 0.91 \\
\cline { 2 - 9 } & Females & 16 & 13.63 & 218 & & \\
\hline
\end{tabular}

$P \leq .05$

Table 6. Differences between students according to specialization

\begin{tabular}{|c|c|c|c|c|c|c|c|}
\hline $\begin{array}{c}\text { Skills in creating } \\
\text { virtual classrooms }\end{array}$ & Group & No & $\begin{array}{c}\text { Mean } \\
\text { Rank }\end{array}$ & $\begin{array}{c}\text { Sum of } \\
\text { Ranks }\end{array}$ & Man-Whitney & Z value & P value \\
\hline \multirow{2}{*}{} & $\begin{array}{c}\text { Islamic } \\
\text { Education }\end{array}$ & 6 & 15.42 & 92.50 & \multirow{2}{*}{48.50} & 0.715 & 0.47 \\
\cline { 2 - 6 } & Arabic Lang. & 20 & 12.93 & 258.50 & & \multirow{2}{*}{} \\
\hline
\end{tabular}

$P \leq .05$

Figure 5. Participant's perceptions that GC is effective in helping in the teaching/learning

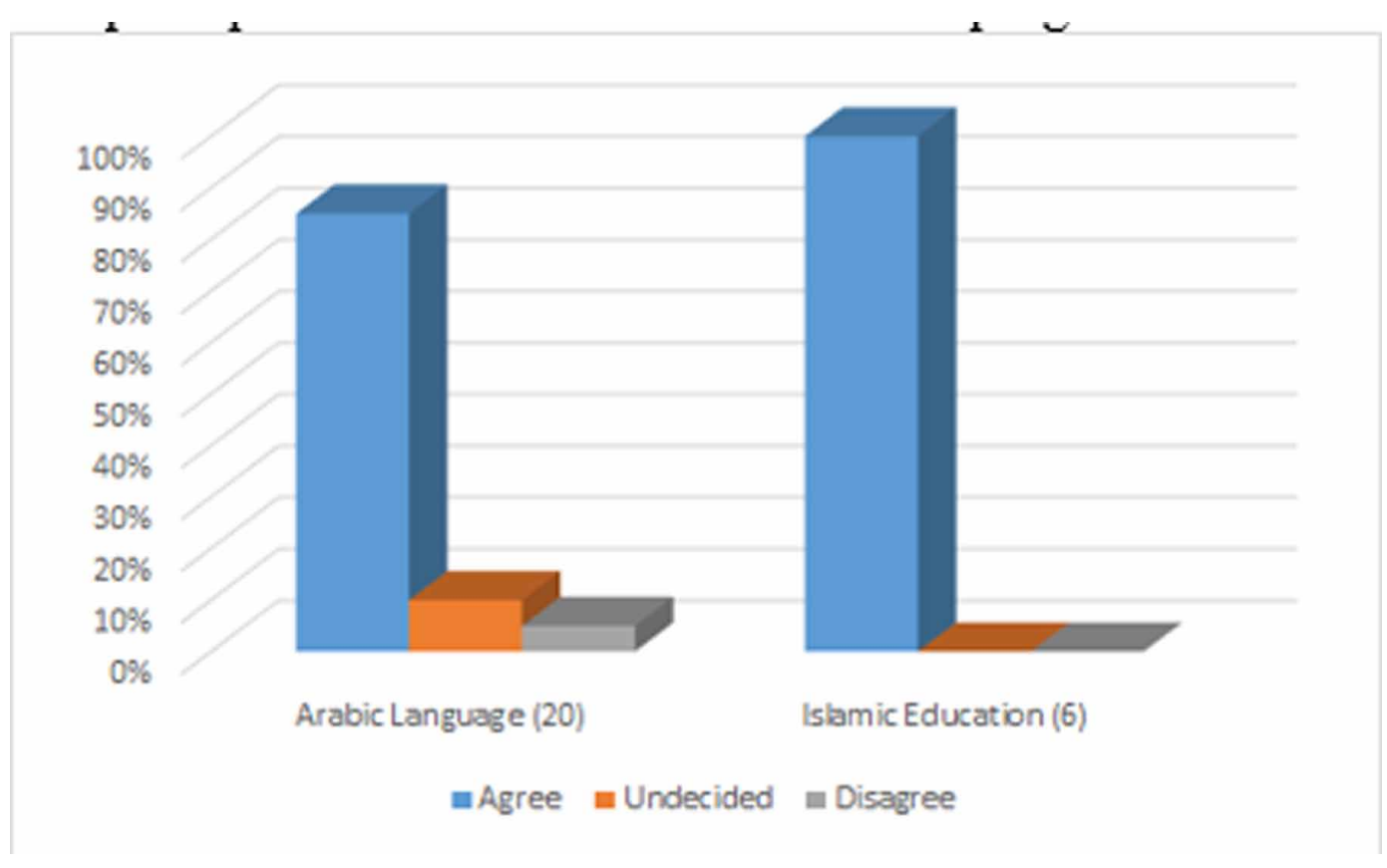

\section{DISCUSSION}

As explained above, the results have shown that the students' skills in creating virtual classrooms using GC application are weak. The result may be attributed to the lack of interest in enriching the university curricula in the relevant programs at the College of Education with the technological innovations essential for education students required for their future career in the education field. Most of the current curricula actually focus on the theoretical side rather than on the practical side. 
In addition to that, the time allocated for the lecture is not enough to allow the teacher focus on such technological applications and ensure that students are empowered with the necessary skills.

Moreover, the results have revealed that there is no statistically significant difference between male and female students' skills. The result may be attributed to the similarity of the learning environment for both male and female students as they are subject to the same preparation in terms of strategies and methods used in teaching, as well as the same content for both of males and females.

Likewise, the results have revealed that there is no statistically significant difference between Arabic language and Islamic education students' skills. The result may be attributed to that students from both specializations were not exposed during their bachelor degree to courses that may contribute to increase their skills in creating the virtual classrooms using GC App.

Although the current study is similar to previous studies in terms of using Google virtual classrooms in the teaching-learning process, it differs in a number of aspects. First, the purpose of the current study was to explore the degree of master students' skills in creating virtual classrooms using GC and their perception of GC, while the previous studies focused on exploring teachers and students' perceptions (Azhar \& Iqbal, 2018; Beaumont, 2018; Peterson, 2013), the effectiveness of GC in teaching or learning certain subjects (Alamour \& Elimat, 2016; Dicisio, 2016), the application influence on future pedagogies (Hegart \& Yoo, 2018), or the factors affecting students' acceptance of GC (Maroof \& Emran, 2018).

Second, the current study sample consisted of Master students at the College of Education in Arabic Language and Islamic Studies specializations. Meanwhile, previous studies sampled teachers, Bachelor students or school students, and pre-service teachers. Third, the current study used a questionnaire, Likert scale and interview as a research instruments, which is similar to the studies of Maroof and Emran (2018) and Dicisio (2016) who also used achievement and vocabulary tests. However, other studies used semi-structured interviews (Azhar \& Iqbal, 2018), surveys, focus groups and observation (Hegart \& Yoo, 2018), achievement post-test (Alamour \& Elimat, 2016), or did not mention the instrument used (Beaumont, 2018; Peterson, 2013).

\section{LIMITATIONS OF STUDY}

The research was limited to a small sample of master students in the College of Education at AAU in two specializations only. Also, the research was conducted during the first semester of academic year 2018/2019. Due to lack of time, the research was limited to exploring the degree of students' skills without addressing the students' perceptions, or any other factors that may affect the level of their skills.

\section{CONCLUSION}

This study has explored the degree of master students' skills at the College of Education in AAU in creating virtual classrooms using GC application. In addition, the study also investigated participants perception of the effectiveness of GC in the teaching /learning process. Based on the results, the study revealed that the degree of students' skills is weak. On the other hand, the perception of the GC was positive and participants assured that GC is easy to create and use. Furthermore, results showed that the majority of participants expressed interest, need and willingness to learn more about GC's creation and usage through training.

This definitely calls for the educators and educationalists at the College to review the curriculum and teaching methods used in order to ensure that students are well equipped with the necessary skills in using various technological applications. This will benefit students to keep abreast with the ongoing developments in ICT and education fields and be effective future teachers.

GC is multipurpose of blended learning, flipped classroom and online classrooms, that is easy to use by teachers and students, paperless and more digital, user-friendly, and allows for collaborative 
work to be undertaken with ease (Beaumont, 2018; Catapano, 2019). The efficient use of GC can pave the way to a better design of courses for teachers which will allow students to succeed in the online environment.

\section{RECOMMENDATIONS}

In conclusion, the researchers would like to raise the following recommendations:

1. Reviewing the programs curricula at the College of Education by focusing more on the innovations in instructional technology in order to prepare students for their career in teaching.

2. Developing the curricula in instructional technology for master students to ensure that the content includes both knowledge and practice in contemporary technological innovations, especially in regard to applications important for eLearning.

3. More attention should be given to increase the master students' skill at the College of Education regardless of their specializations.

4. Designing a training program that will assist master students acquire the required skills in creating virtual classrooms using GC application. 


\section{REFERENCES}

Abdulrazeq, E. E. (2010). Designing a proposed program based on the educational needs to equip computer teachers with skills of creating virtual classroom tools for computer courses on the Internet and its impact in developing their attitudes toward virtual e-learning. Journal of Instructional Technology, 20(3), 93-184.

Abdulhamid, M. (2005). Networking learning system. Cairo: The World of Books.

Abu Aliya, A. (2013). Teacher's Guide to E-Learning System. Zarqa, Jordan: Center for E-Learning, Zarqa University.

Al-Amour, Y. S., \& Alimat, M. M. (2016). The Effectiveness of the Google Classroom Program on Acquiring Bio-Scientific Concepts in the Blood Unit of the 10th Grade Students in the Naqab District of Palestine 48. Journal of Educational and Psychological Sciences, 4(24), 144-164.

Al-Raheely, T. (2013). The impact of using some of Google educational apps in academic attainment and social intelligence among female students in Tayba University (Unpublished Ph.D. thesis). Um Al-Qura University, Saudi Arabia.

Al-Salem, A. M. (2004). Technology of education and e-learning. Al Rasheed Library.

Al-Talwaty, R. (2014). What are Virtual Classrooms? Retrieved from https://www.new-educ.com/les-classesvirtuelles

Amin, S. N. (2013). An effective use of ICT for education and learning by drawing on worldwide knowledge, research and experience: ICT as a change agent for education (A Literature review). Scholarly Journal of Education, 2(4), 38-45.

Arrieta, H. (2016). The impact of ICTs: Advantages and disadvantages in academic performance of 5th year students at the technical school. Retrieved from http://redi.ufasta.edu.ar:8080/xmlui/bitstream/ handle/123456789/1142/2015_ING_012.pdf?sequence=1

Azhar, K. A., \& Eqbal, N. (2018). Effectiveness of Google Classroom: Teachers' perceptions. Prizren Social Science Journal, 21, 52-66.

Beaumont, K. (2018). GC: An online learning environment to support blended learning. Compass (Eltham), 11(2). Advance online publication. doi:10.21100/compass.v11i2.837

Catapano, J. (2019). Technology in the classroom: A look at Google classroom. Retrieved from https://www. teachhub.com/technology-classroom-look-google-classroom

Clark, H., \& Avrith, T. (2017). The Google Infused Classroom. Irvine, CA: EdTechTeam Press.

Dale, E. (1969). Audio-visual methods in teaching. Dryden.

Dicicco, K. (2016). The effects of Google Classroom on teaching social studies for students with learning disabilities (Unpublished master thesis). Rowan University.

Dillman, D. A. (2000). Mail and Internet surveys-The tailored design method. John Wiley \& Sons, Inc.

Dweidri, R. W. (2000). Scientific research and its theoretical foundations and practice. Contemporary Thought House.

El Mansour, B., \& Mupinga, D. M. (2007). Students' Positive and Negative Experiences in Hybrid and Online Classes. College Student Journal, 41(1), 242-248. Retrieved January 24, 2021, from https://www.learntechlib. org/p/101004/

Faramawy, B. (2010). The impact of the use of electronic classrooms on the educational achievement of students of educational technology (Unpublished master thesis). Menoufia University, Egypt.

Gall, M. D., Gall, J. P., \& Borg, W. R. (2007). Educational research: An introduction (8th ed.). Allyn and Bacon.

Google. (2013). Discover a better way of learning: Free web-based email, calendar \& documents for collaborative study anytime, anywhere. Retrieved from http://www.google.com/enterprise/ apps/education 
Google for Education. (2018). Google Classroom. Retrieved from https://edu.google.com/intl/en_uk/products/ productivity-tools/classroom/

Guarte, J. M., \& Barrios, E. (2006). Estimation Under Purposive Sampling. Communications in Statistics. Simulation and Computation, 35(2), 277-284. doi:10.1080/03610910600591610

Barrios, E. B. (2006). Estimation Under Purposive Sampling. Communications in Statistics. Simulation and Computation, 35(2), 277-284. doi:10.1080/03610910600591610

Heggart, K., \& Yoo, J. (2018). Getting the most from Google classroom: A pedagogical framework for tertiary educators. The Australian Journal of Teacher Education, 3(43), 140-153. doi:10.14221/ajte.2018v43n3.9

Khalif, Z. N. (2011). Using virtual classrooms from the perspective of teachers and high school students in Palestine. Paper presented at the Second International Conference on e-Learning and Distance Education, Riyadh, Saudi Arabia.

Kihoza, P., Zlotnikova, I., Bada, J., \& Kalegele, K. (2016). Classroom ICT integration in Tanzania: Opportunities and challenges from the perspectives of TPACK and SAMR models. International Journal of Education and Development Using Information and Communication Technology, 12(1), 107-128.

Logofatu, B., Visan, A., \& Ungureanu, C. (2015). Google classroom - The new educational challenge: Pilot test within the department for distance learning. eLearning \& Software for Education, 2, 493-499.

Maroof, R. S., \& Emran, M. (2018). Students' acceptance of Google classroom: An exploratory study using PLS-SEM approach. iJET, 13(6), 112-123. Retrieved from 10.3991/ijet.v13i06.8275

Mwanza, D., \& Engestrom, Y. (2005). Managing content in E-Learning environments. British Journal of Educational Technology, 36(3), 324-340. doi:10.1111/j.1467-8535.2005.00479.x

Nassaji, H. (2015). Qualitative and descriptive research: Data type versus data analysis. Language Teaching Research, 19(2), 129-132. doi:10.1177/1362168815572747

Parker, A. V., \& Gerber, B. L. (2002). Performance based assessment, science festival exhibition presentations, and elementary science achievement. Journal of Elementary Science Education, 14(1), 59-67. doi:10.1007/ BF03174737

Petersen, J. (2013). An introduction and overview to Google apps in K12 education: A web-based instructional module. Retrieved from https://core.ac.uk/download/pdf/10600398.pdf

Puentedura, R. (2003). An Introduction. Retrieved from http://www.hippasus.com/rrpweblog/archives/000001. html

Richards, J. C., \& Schmidt, R. (2002). Longman dictionary of language teaching and applied linguistics (3rd ed.). Longman.

Rion, M. Z., \& Hasan, M. M. (2015). An implementation of virtual classroom and performance analysis of teaching-learning outcome. Global Journal of Computer Science and Technology, 15(7), 7-14.

Rizq, F. M. (2009). The effect of virtual classrooms on self-efficacy beliefs and instructional performance of pre-service science teachers. Journal of Reading and Knowledge, 90, 212-257.

Şahin, F. (2013). The scale for rating the behavioral characteristics of gifted and talented students: Study of factor structure, reliability and validity. Journal of Educational Sciences, 38, 119-138.

Sayed, M. A. (2017). Use of virtual classrooms to develop cognitive achievement and self-organization skills for students in the first-grade secondary in history. Journal of Scientific Research in Education, 18, 371-388.

Skaik, H. (2016). Academics' knowledge sharing behaviour in United Arab Emirates. LAP LAMBERT Academic Publishing.

Sviridova, T., Sviridova, L., \& Tymoshenko, B. (2011). Google Apps as solution of communication issues in educational process. Proceedings from IEEE 7th International Conference, 183-184.

Tan, J. P., Choo, S. S., Kang, T., \& Liem, G. A. (2017). Educating for twenty-first century competencies and future-ready learners: Research perspectives from Singapore. Asia Pacific Journal of Education, 37(4), 425-436. doi:10.1080/02188791.2017.1405475 
Zaitoun, A., \& Abdullah, F. (2008). Self-learning competencies and skills. Damascus, Syria: Dar Al-Elm and Eman for Publishing and Distribution.

Zuhrieh Shana possesses over 20 years of teaching, consulting, training and research experience in different academic institutions in USA, Saudi Arabia, Canada and the United Arab Emirates. Most recently, she served as the Associate Professor of Educational Technology at the Faculty of Education at Al-Ain University (AAU), UAE. In the past fifteen years, she conducted several researches in the field of educational technology and community development. Dr. Shana has also designed and developed educational software as a part of a Research Agenda focused on Educational Reform for Student Success in UAE.

Tareq Alyatim has a Master of Education in Arabic Language Curricula and Instruction from AI Ain University, UAE. He's currently working toward his PhD degree in Arabic Language curricula and its teaching methodologies at University of Malaya - Malaysia. Alyatim has over 14 years of experience in teaching Arabic Language. Among his many interests is exploring how to combine the possibilities of technology-enhanced, problem-based, and learner-centered pedagogies to augment student learning.

Mohammad Alkhazaleh is an Associate Professor in Educational Technology at the Faculty of Education at AlAin University (AAU), UAE. In the past fifteen years, he conducted several researches in the field of educational courses. He possesses over 20 years of teaching (graduate and undergraduate), consulting, training, and research experience in different academic institutions.

Nahla Alshalbi has a PhD degree in Arabic language from Yarmouk University, Jordan. Currently, she is an Associate Professor in Arabic Language Department at the Faculty of Education at Al-Ain University (AAU), UAE. 